Chapter 4

\title{
Ceramic Biomaterials for Tissue Engineering
}

Sandra Pina ${ }^{1,2}$, Rui. L. Reis ${ }^{1,2}$ and Joaquim M. Oliveira ${ }^{1,2}$

'3B's Research Group - Biomaterials, Biodegradables and Biomimetics, University of Minho, Headquarters of the European Institute of Excellence on Tissue Engineering and Regenerative Medicine, AvePark - Parque de Ciência e Tecnologia, Zona Industrial da Gandra, 4805-017 Barco, Guimarães, Portugal; ${ }^{2} I C V S / 3 B$ 's - PT Government Associate Laboratory, Braga/Guimarães, Portugal.

\section{LIST OF ABBREVIATIONS}

ATZ Alumina-toughened zirconia

BMPs Bone morphogenetic proteins

CaPs Calcium phosphates

CPCs Calcium phosphates cements

ECM Extracellular matrix

HA Hydroxyaptite

hBMSCs Human bone marrow stromal cells

MSCs Mesenchymal stem cells

RBMSCs Rat bone marrow stromal cells

$\boldsymbol{\beta}$-TCP $\beta$-tricalcium phosphate

TE Tissue engineering

TZP Zirconia polycrystals

ZTA Zirconia-toughened alumina

\begin{abstract}
Bioceramics, natural and synthetic, are designed to induce a strong bonding to bone and appeared as an alternative to metallic implants. Bioceramic materials currently used for the repair and reconstruction of hard and soft tissues can be categorized according its composition, structure, and properties. These biomaterials are grouped bioinert ceramics as alumina and zirconia, bioactive glasses and glass ceramics and bioresorbable calcium phosphates-based materials. The bioceramics concepts, namely physico-chemical, mechanical and biological properties, and respective applications in diverse fields of tissue engineering are discussed in depth herein. An upto-date of bioceramics clinical trials is also considered. Based on the stringent requirements for
\end{abstract}


clinical application, prospects for the development of advanced functional bioceramics for tissue engineering are highlighted for the future.

\section{KeyWords}

Bioceramics; Natural-origin bioceramics; Alumina and zirconia; Bioactive glasses and glassceramics; Calcium phosphates; Calcium phosphate cements; Bioactivity; Biocompatibility; Bone regeneration; Tissue engineering.

\subsection{INTRODUCTION}

Bioceramics, natural or synthetic origin, are a class of inorganic and non-metallic ceramics used for repair and regeneration of diseased and damaged parts of the musculoskeletal system and periodontal anomalies. These ceramic materials have been developed for orthopedic load-bearing coatings (hip acetabular cups), bone grafts and cements, and dental implants (1). Bioceramics are typically characterized by their excellent biocompatibility, osteoconductivity, corrosion resistance, and a hard brittle surface. Weaknesses of bioceramics include poor fracture toughness, brittleness, very low elasticity and extremely high stiffness (2). Consequently, their clinical applications for tissue engineering (TE) has been limited. In general, bioceramics are classified as:

- Bioinert: has no interaction with its surrounding tissue after implantation. They have a reasonable fracture toughness, and resistance to corrosion and wear. These ceramics are typically used as structural-support implants, such as bone devices and femoral head. Examples of bioinert ceramics are alumina and zirconia.

- Bioactive: bond directly with living tissues after implantation, with the pattern of bonding osteogenesis. These ceramics are brittle and has been applied for the filling of small bone defects and periodontal irregularities. Examples are bioglasses and glass-ceramics.

- Bioresorbable: gradually absorbed in vivo and is replaced by bone over time. Examples are calcium phosphates (CaPs), calcium phosphate cements (CPCs), and calcium carbonates or calcium silicates.

Current efforts center considerable attention in TE involving bioceramics for developing 3D-based scaffolds able to mimic the structural, mechanical and biological properties of natural tissues (3, 4). Moreover, to stimulate cells differentiation and extracellular matrix (ECM) production during the regeneration process, are also important issues to be considered envisioning the formation of new tissues. Bioceramics are stronger under compression and weak under tension and these facts need to be contemplated when fabricating scaffolds for particular biomedical application. These structures hold porous and fibrous scaffolds, and hydrogels, with defined architecture, controlled degradation rate, and optimized porosity and pore interconnectivity. Scaffold fabrication techniques include sponge replica method, solvent casting and particulate-leaching, freeze drying, gas foaming and phase separation, rapid prototyping and electrospinning (4-11). The latter two 
ones are extremely attractive in their ability to mimic new tissue structures and with the possibility of incorporating pharmaceutical agents, even though are expensive and suffer from the materials choice and costs. Additionally, additive manufacturing such as bioprinting and bioinks have presenting a high potential in combination with the design and imaging techniques bringing innovations at the micro- and nano-scale to regenerative medicine (12).

An array of natural and synthetic bioceramics has been proposed to be used in the processing TE scaffolding with specific composition, microstructure and long-term reproducibility. Bioceramics from natural origin, such as corals, nacres, sponges, and animal (fish and chicken) bones, also provide an abundant source of calcium compounds (e.g., calcium carbonate and calcium phosphate) for skeletal TE applications (13). Coral-derived materials has been widely used as raw materials to preparing $\mathrm{CaPs}$ biomaterials for bone tissue regeneration, due to their unique microstructural composition and mechanical properties. Our group has been proposing a variety of red algae (e.g., Coralline officinallis) to produce porous ceramics aiming bone repair and regeneration $(14,15)$. This process involves the conversion of calcium carbonate skeletons of $C$. officinallis particulates into CaPs with hydroxyapatite (HA) nanocrystallites, while maintaining the native microstructure of the red algae, using a thermal and chemical treatment (14).

Concerning synthetic bioceramics, alumina and zirconia, bioactive porous glasses and glassceramics, and CaPs-based materials in the form of sintered ceramics, coatings and cement pastes, are the ones mostly used in TE applications $(16,17)$. These bioceramics can be prepared by several methods (e.g. wet precipitation, hydrolysis, sol-gel synthesis, hydrothermal synthesis, mechanochemical synthesis, microwave processing, or spray drying methods) yielding materials with different properties, such as crystal size and morphology. Among them, wet precipitation method has the advantage on the homogeneity of the final product, and the easiness of controlling parameters (e.g. temperature, $\mathrm{pH}$, and the presence of additives) during synthesis (18).

Many studies are dedicated on bioceramic materials incorporating ionic elements (e.g. strontium, zinc, magnesium, manganese, silicon) that would be released during bone graft resorption, and hence can influence bone health and enhance biocompatibility, while strengthening the mechanical properties of the implants (19-23). Besides, minerals and traces of metal elements may provide physicochemical modifications in the produced materials, which can accelerate bone formation and resorption in vivo $(24,25)$.

This chapter aims at presenting a concise and reachable overview of bioceramics for applications in the contexts of musculoskeletal and periodontal tissue regeneration. A range of materials are considered, from bioinert to bioactive and bioresorbable bioceramics. Particularly, emphasis is set on synthetic bioceramics physicochemical, mechanical and biological properties. Clinical trials involving bioceramics, challenges and future prospects of research in this field are also underlined.

\subsection{BIOCERAMIC MATERIALS CONCEPTS}

\subsubsection{Alumina and Zirconia}


Alumina $\left(\mathrm{Al}_{2} \mathrm{O}_{3}\right)$ and $\mathrm{Zirconia}\left(\mathrm{ZrO}_{2}\right)$ are well known for their general chemical inertness, high strength, hardness, cracking, and corrosion resistance, thus being recognized as bioinert ceramics successfully used in orthopedics, specifically for total hip/knee arthroplasty, and in dental repair/replacement (Figure 1) $(26,27)$.

Alumina-based bioceramics were the first commercially available for dental implantation and acetabular cup replacement in total hip prostheses (28). Alumina favorably combine high hardness and high abrasion resistance, associated with its surface energy and smoothness. Hence, this bioceramic has been used as synthetic bone grafts or as porous prosthetic device, by using a biomimetic coating on alumina in order to provide a stable bond with the host tissue. Further clinical applications of alumina prostheses include bone screws, alveolar ridge (jaw bone) and maxillofacial reconstruction, ossicular (middle ear) bone substitutes, corneal replacements, segmental bone replacements, and blade and screw and post-type dental implants (29). However, the alumina ceramics have low fracture toughness, which can be significantly improved by adding zirconia (known as zirconia-toughened alumina (ZTA) or alumina-toughened zirconia (ATZ)) resulting in a composite material with enhanced toughness and tribological properties $(30,31)$. ZTA comprises alumina (70-95\%) matrix phase and zirconia polycrystals (TZP) (5-30\%) as the secondary phase, thus combining the advantageous properties of monolithic alumina and zirconia. In addition, the wear properties and low susceptibility to stress-assisted degradation of alumina ceramics is also preserved in ZTA ceramics, reducing the risk of impingement and dislocation, and improving stability (31).

In consequence of its polymorphic crystalline structure - monoclinic, tetragonal, and cubic zirconia-based bioceramics, namely tetragonal TZP, have been widely popular in bone TE, due to their excellent fracture toughness, high strength, elastic modulus, and wear resistance (32). For example, partially stabilized zirconia (with yttria, $\mathrm{CaO}$, and $\mathrm{MgO}$ ) materials are known to have flexural strength above $1,000 \mathrm{MPa}$ and fracture toughness higher than $8 \mathrm{MPam}^{1 / 2}(33,34)$. Besides its mechanical properties, zirconia promotes cell proliferation and differentiation in osteogenic pathways, as well as osseointegration, and has radiopaqueness that helps the monitoring in radiographs (35). Zirconia has often been used in dentistry since it has the advantage of being coloured to match the shade of any existing teeth. 


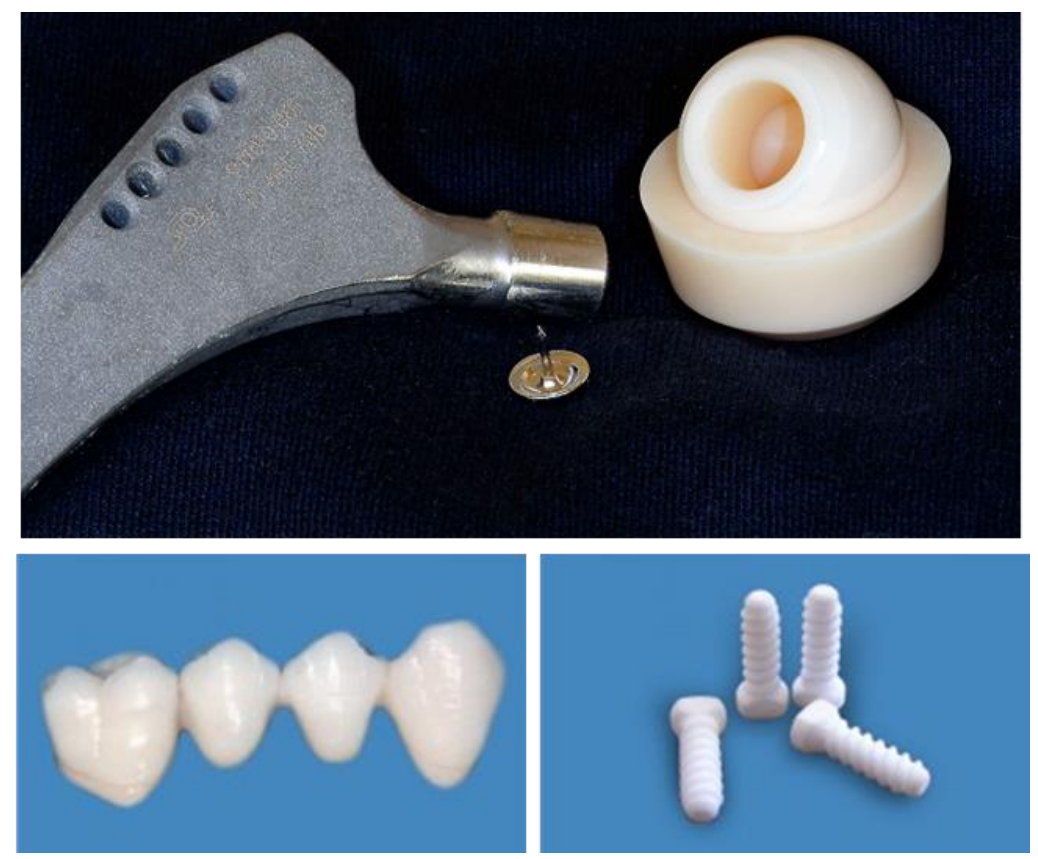

FIGURE 1. Examples of alumina/zirconia bioceramics for hip joint prosthesis and dentistry (36, 37).

\subsubsection{Bioactive glasses and glass-ceramics}

Bioactive glasses and glass-ceramics have been developed for TE applications, in both orthopedic and dental field, in dense and porous form (Figure 2) (38-40). Glass-ceramics are crystallized glasses resultant from thermal treatment of its parent glasses, with superior strength and toughness, elastic modulus, and wear resistance.

Bioactive glasses have unique properties with ability to bond to both hard and soft connective tissues more rapidly than other bioceramics, converting into an amorphous calcium phosphate or hydroxyapatite material after implantation. Moreover, it is also reported that the ions $\mathrm{Si}, \mathrm{Ca}, \mathrm{P}$ and $\mathrm{Na}$, released during dissolution of certain bioactive glasses compositions appear to activate expression of osteogenic genes, and to stimulate neovascularisation and angiogenesis, enzymatic activity, and differentiation of mesenchymal stem cells (MSCs) (41-43).

The pioneering work in the field of bioactive glasses, for biomedical applications, data from the beginning of the 1970s with the development of 45S5 Bioglass ${ }^{\circledR}$ by Larry Hench (29). Bioglass ${ }^{\circledR}$, is a silica-based bioactive glass in the $\mathrm{Na} 2 \mathrm{O}-\mathrm{CaO}-\mathrm{SiO}_{2}-\mathrm{P}_{2} \mathrm{O}_{5}$ system with a composition close to a ternary eutectic in the $\mathrm{Na}_{2} \mathrm{O}-\mathrm{CaO}-\mathrm{SiO}_{2}$ diagram. This type of glass has also the particularity of stimulates bone growth away from the bone-implant interface, which mechanism can be attributed to a hydroxycarbonate apatite layer on the surface of the glass $(40,44,45)$.

Besides silicate glasses, phosphate-based and borate-based glasses are other types of bioactive glasses developed for biomedical use. Phosphate bioactive glasses, in the $\mathrm{Na} 2 \mathrm{O}-\mathrm{CaO}-\mathrm{P}_{2} \mathrm{O}_{5}$ system, have faster dissolution in aqueous fluids, than that for silica glasses, useful in the healing of chronic wounds and as carriers in drug delivery such as antibacterial ions and complex organic molecules 
for chemotherapy applications $(46,47)$. By its turn, borate-based glasses, in the $\mathrm{B}_{2} \mathrm{O}_{3}-\mathrm{Na}_{2} \mathrm{O}-\mathrm{CaO}$ $\mathrm{P}_{2} \mathrm{O}_{5}$ system, have fast degradation rates and are able to completely convert into apatite when immersed in an aqueous phosphate solution following a similar process of Bioglass $\AA$, but without the formation of a silica-rich layer $(48,49)$. Borate glasses have been also used as drug release systems in the treatment of bone infection (50). A concern associated with these type of glasses is the toxicity of boron released into the solution as borate ions, which can be reduced in in vitro dynamic culture conditions (51).

The common methods of synthesis of bioactive glasses include conventional melt-quenching, solgel process, flame synthesis and microwave irradiation $(52,53)$.
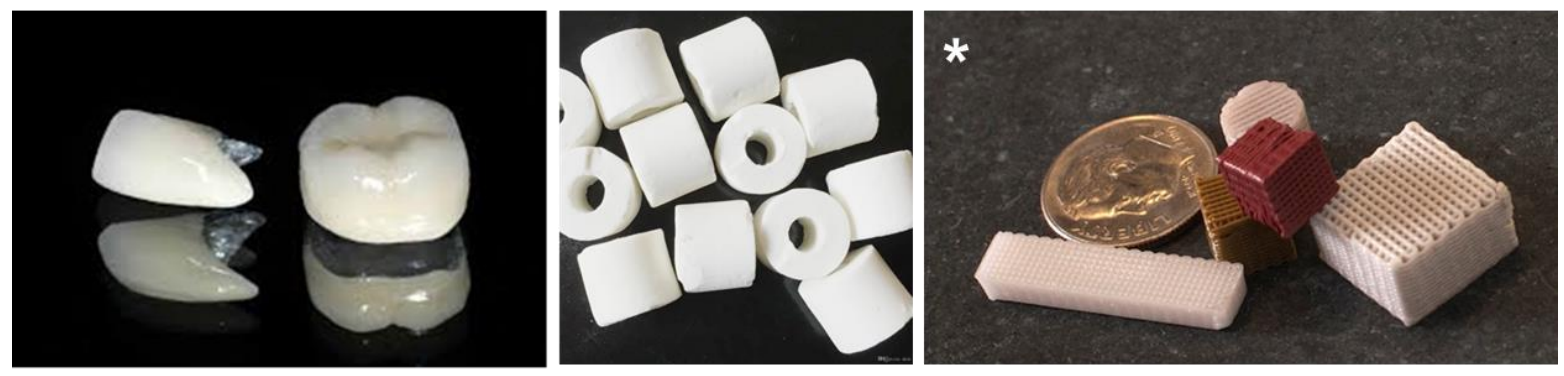

FIGURE 2. Bioactive glass and glass-ceramics for biomedical applications and porous robocast bioglass produced at Missouri University of Science and Technology for bone repair and regeneration $(*)(54,55)$.

\subsubsection{Calcium phosphates}

Calcium phosphates (CaPs) are the chemical compounds of special interest for TE applications due to their close resemblance with the inorganic part of major normal and pathological calcified tissues of mammals (56-58). These types of bioceramics hold an outstanding biological performance, such as biocompatibility, osteoconductivity and bioresorbability, thus integrating into living tissue by the same processes active in bone remodeling. Besides, CaPs are easy to produce with a low cost, and can be relatively easily certified as medical grade. Despite that, CaPs are limited to load-bearing applications due to their poor mechanical properties, namely, strength and fatigue resistance, being primarily used as fillers and coatings in the biomedical field $(56,59)$. However, CaPs bioceramics are also available in particles, dense or porous blocks, injectable compositions, implant coatings, and composites with polymers (Figure 3). Custom-designed forms as wedges for tibial opening osteotomy, cones for spine and knee, and inserts for vertebral cage fusion, are also available. CaPs are used in alveolar ridge augmentation, tooth replacement, maxillofacial reconstruction, orbital implants, increment of the hearing ossicles, spine fusion and repair of bone defects (60). 


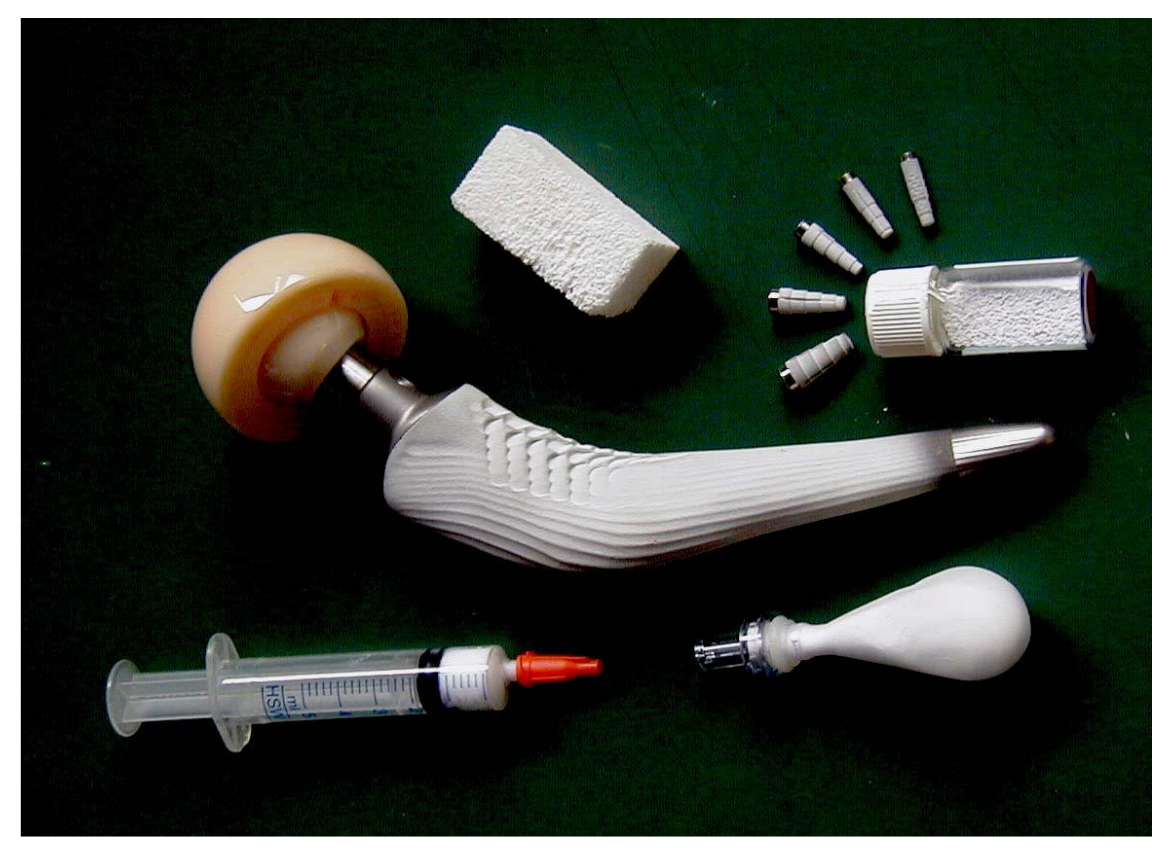

FIGURE 3. Commercial calcium phosphate-based bone graft materials, such as porous blocks, powders and granules, and HA coating on femoral metal stem. Reprinted from Ref. (57), with permission.

The most known CaPs, listed in Table 1.1, comprise $\mathrm{Ca} / \mathrm{P}$ molar ratios in the range of $0.5-2$, depending on their acidity and solubility. $\mathrm{CaP}$ is more acidic and water-soluble for lower $\mathrm{Ca} / \mathrm{P}$ molar ratios (61). The majority of CaPs are sparingly soluble in water, but, all of them are easily soluble in acids but insoluble in alkaline solutions. According to solubility, CaPs can be ranked in order of increasing the in situ degradation rate as: $\mathrm{MCPM}>\mathrm{TTCP} \approx \alpha$-TCP $>$ DCPD $>$ OCP $>\beta$ TCP > HA. 
Table 1.1: Main calcium phosphates used for biomedical applications $(3,57)$.

\begin{tabular}{|c|c|c|c|c|}
\hline $\begin{array}{l}\text { Calcium } \\
\text { phosphate }\end{array}$ & Formula & $\begin{array}{l}\mathrm{Ca} / \mathrm{P} \\
\text { molar } \\
\text { ratio }\end{array}$ & $\begin{array}{l}\text { pH stability } \\
\text { range in } \\
\text { aqueous } \\
\text { solutions at } \\
25^{\circ} \mathrm{C} \\
\end{array}$ & Properties \\
\hline $\begin{array}{l}\text { Monocalcium } \\
\text { phosphate } \\
\text { monohydrate } \\
(\mathrm{MCPM})\end{array}$ & $\mathrm{Ca}\left(\mathrm{H}_{2} \mathrm{PO}_{4}\right)_{2} \cdot \mathrm{H}_{2} \mathrm{O}$ & 0.5 & $0.0-2.0$ & Not biocompatible \\
\hline $\begin{array}{l}\text { Monocalcium } \\
\text { phosphate } \\
\text { anhydrous } \\
\text { (MCPA) }\end{array}$ & $\mathrm{Ca}\left(\mathrm{H}_{2} \mathrm{PO}_{4}\right)_{2}$ & 0.5 & $\begin{array}{l}\text { Stable at } \mathrm{T} \\
>100^{\circ} \mathrm{C}\end{array}$ & \\
\hline $\begin{array}{c}\text { Dicalcium } \\
\text { phosphate } \\
\text { dihydrate } \\
\text { (DCPD) }\end{array}$ & $\mathrm{Ca}\left(\mathrm{HPO}_{4}\right) \cdot 2 \mathrm{H}_{2} \mathrm{O}$ & 1.0 & $2.0-6.0$ & $\begin{array}{l}\text { Biocompatible, } \\
\text { biodegradable and } \\
\text { osteoconductive }\end{array}$ \\
\hline $\begin{array}{c}\text { Dicalcium } \\
\text { phosphate } \\
\text { anhydrous } \\
\text { (DCPA) }\end{array}$ & $\mathrm{Ca}\left(\mathrm{HPO}_{4}\right)$ & 1.0 & $\begin{array}{l}\text { Stable at } \mathrm{T} \\
>100^{\circ} \mathrm{C}\end{array}$ & \\
\hline $\begin{array}{l}\text { Octacalcium } \\
\text { phosphate } \\
\text { (OCP) }\end{array}$ & $\begin{array}{c}\mathrm{Ca}_{8}\left(\mathrm{HPO}_{4}\right)_{2}\left(\mathrm{PO}_{4}\right) \\
4.5 \mathrm{H}_{2} \mathrm{O}\end{array}$ & 1.33 & $5.5-7.0$ & $\begin{array}{l}\text { Metastable precursor } \\
\text { of CaPs that } \\
\text { transforms into HA }\end{array}$ \\
\hline $\begin{array}{l}\text { Amorphous } \\
\text { calcium } \\
\text { phosphate } \\
\text { (ACP) }\end{array}$ & $\begin{array}{c}\mathrm{Ca}_{\mathrm{x}} \mathrm{H}_{\mathrm{y}}\left(\mathrm{PO}_{4}\right)_{\mathrm{z}} \cdot \mathrm{nH}_{2} \\
\mathrm{O} \\
(\mathrm{n}=3-4.5)\end{array}$ & $1.2-2.2$ & $\begin{array}{c}\sim 5-12 \\
\text { (Always } \\
\text { metastable) }\end{array}$ & $\begin{array}{c}\text { Lacks long range } \\
\text { order }\end{array}$ \\
\hline $\begin{array}{c}\text { Calcium- } \\
\text { deficient } \\
\text { hydroxyapatite } \\
\text { (CDHA) }\end{array}$ & $\begin{array}{c}\mathrm{Ca}_{9}\left(\mathrm{HPO}_{4}\right)\left(\mathrm{PO}_{4}\right)_{5} \\
(\mathrm{OH})\end{array}$ & $1.5-1.67$ & $6.5-9.5$ & Poorly crystalline \\
\hline $\begin{array}{c}\beta \text {-Tricalcium } \\
\text { phosphate }(\beta- \\
\text { TCP) }\end{array}$ & $\beta-\mathrm{Ca}_{3}\left(\mathrm{PO}_{4}\right)_{2}$ & 1.5 & $\begin{array}{l}\text { Cannot be } \\
\text { precipitated } \\
\text { from } \\
\text { aqueous } \\
\text { solutions }\end{array}$ & Biodegradable \\
\hline $\begin{array}{c}\alpha \text {-Tricalcium } \\
\text { phosphate }(\alpha- \\
\text { TCP })\end{array}$ & $\alpha-\mathrm{Ca}_{3}\left(\mathrm{PO}_{4}\right)_{2}$ & 1.5 & $\begin{array}{l}\text { Cannot be } \\
\text { precipitated } \\
\text { from } \\
\text { aqueous } \\
\text { solutions }\end{array}$ & \\
\hline
\end{tabular}




\begin{tabular}{|c|c|c|c|c|}
\hline $\begin{array}{c}\text { Hydroxyapatit } \\
\text { e (HA) }\end{array}$ & $\mathrm{Ca}_{10}\left(\mathrm{PO}_{4}\right)_{6}(\mathrm{OH})_{2}$ & 1.67 & $9.5-12$ & Osteoconductive \\
\hline $\begin{array}{c}\text { Tetracalcium } \\
\text { phosphate } \\
\text { (TTCP) }\end{array}$ & $\mathrm{Ca}_{4}\left(\mathrm{PO}_{4}\right)_{2} \mathrm{O}$ & 2.0 & $\begin{array}{c}\text { Cannot be } \\
\text { precipitated } \\
\text { from } \\
\text { aqueous } \\
\text { solutions }\end{array}$ & $\begin{array}{c}\text { Biocompatible but } \\
\text { poorly biodegradable }\end{array}$ \\
\hline
\end{tabular}

Attention in the biomedical field is generally focused on HA, $\alpha$ - and $\beta$-TCP, CDHA and biphasic $\mathrm{CaPs}$, since implants made of calcined HA stay in bone defects for many years upon implantation $(56,62)$. HA is crystalline and is the most stable and least soluble CaPs in an aqueous solution below pH 4.2 (56). HA can be produced using wet methods, such as precipitation method, hydrothermal synthesis and solid-state reaction of, for example, MCPM, DCPA, DCPD, OCP, above $1200^{\circ} \mathrm{C}(63-66)$. $\beta$-TCP is a high temperature phase of $\mathrm{CaPs}$, obtained by thermal decomposition at temperatures above $800^{\circ} \mathrm{C}$. $\beta$-TCP is biodegradable and has been extensively used as bone substitute, either as granules or blocks, or even in CaPs-based bone cements (57). It has been reported that the biological resorption capability of HA and $\beta$-TCP is different though their similarity in terms of chemical composition. HA has a slow resorption rate and may remain integrated into the regenerated bone tissue after implantation, whereas $\beta$-TCP is completely reabsorbed $(67,68)$. Therefore, clinical applications have been performed using the biphasic CaPs, as a result of combining HA and $\beta$-TCP, thus improving the bioresorbability and strength of the bone substitutes $(62,66,69)$. $\alpha$-TCP is usually prepared from $\beta$-TCP phase at heat treatment above $1125^{\circ} \mathrm{C}$, and quenching it prevents the reverse transformation (70). $\alpha$-TCP is biocompatible, and more biodegradable and reactive than $\beta$-TCP (71). CDHA is obtained by precipitation in an aqueous solution above a $\mathrm{pH} 7$ (56). Their crystals are in general poorly crystalline and of submicron dimensions. The solubility of CDHA increases with a decrease of $\mathrm{Ca} / \mathrm{P}$ molar ratio, crystallinity and size. CDHA can decompose into $\beta$-TCP, into a mixture of HA and $\beta$-TCP or into pure $\mathrm{HA}$, when heating above $700^{\circ} \mathrm{C}(62,72)$. As a first approximation, $\mathrm{CDHA}$ may be considered as HA with some ions missing (73).

\subsubsection{Calcium phosphates-based cements}

In 1832, Ostermann prepared a CaP biomaterial in the form of a paste that set in situ to form a solid material. Nevertheless, Brown and Chow in 1986 (74) were the first to present this new form of CaPs, currently known as calcium phosphate-based cements (CPCs).

CPCs result from the mixture of one or several CaPs and an aqueous solution, which then precipitate into a less soluble $\mathrm{CaP}$ and sets by the entanglement of the growing crystals, providing mechanical stiffness to the cement, and then, the paste can be placed into the bone defect (Figure 4). Subsequently it hardens in situ, at body temperature, and then displays limited solubility. 
CPCs salient features are excellent biocompatibility and resorbability, bioactivity, noncytotoxicity, development of osteoconductive pathways and sufficient compressive strength for a number of applications $(56,67,75,76)$. CPCs are mechanically much stronger in compression than in tension or shear, because entangled crystals are not well bonded. Compressive strength values are typically 5-10 times larger than that of tensile strength. The foremost advantages of the CPCs include fast setting, excellent mouldability and manipulation. Hence, these bioceramics are commonly used to fill bone defects and trauma surgeries as mouldable paste-like bone substitute materials. Besides, like any other bioceramics, CPCs provide the opportunity for bone grafting using alloplastic materials, which are unlimited in quantity and provide no risk of infectious diseases.

CPCs can be classified according to their end product into apatite (AP) cements and dicalcium phosphate dehydrate (DCPD or brushite) cements, upon the $\mathrm{pH}$ value of a cement paste after setting. AP is formed above $\mathrm{pH} 4.2$, whereas brushite is preferentially formed when $\mathrm{pH}$ value of the paste is < 4.2, although it may grow even up to $\mathrm{pH} 6.5$, due to kinetics reasons $(77,78)$. Brushite cements have raised interest due to their higher solubility and resorbability in vivo much faster than AP cements. Although AP cements show higher mechanical strength, they have slow in vivo resorption rates that interfere with the bone regeneration process $(79,80)$. Moreover, brushitebased cements possess faster setting reactions $(19,81)$.
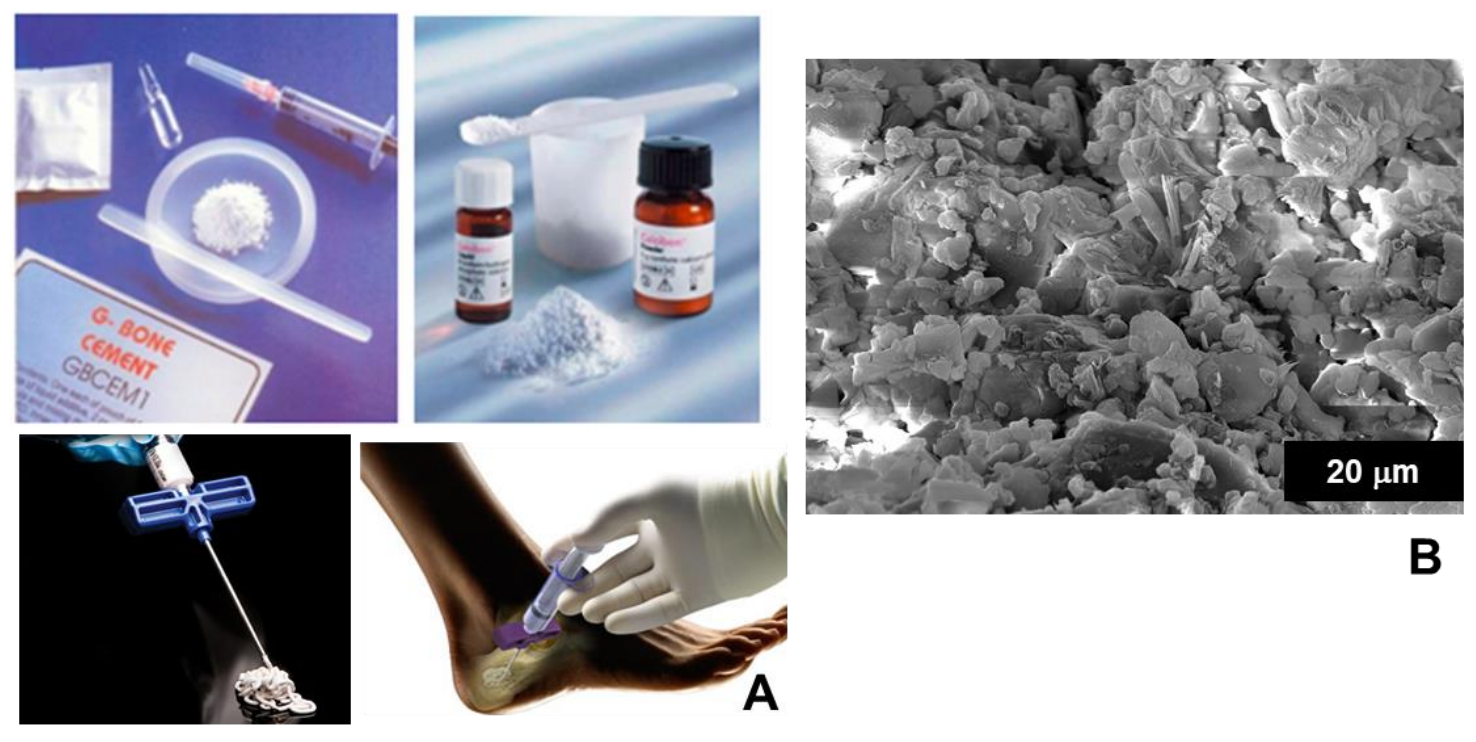

FIGURE 4. A) Self-setting CPCs pastes resultant from CaPs powders and an aqueous solution that then can be injected into the bone defect; and B) Brushite cement microstructure after hardening, showing entangled growing crystals, which provides the mechanical stiffness to the cement (82, 83). Reprinted from Ref.(83), with permission. 


\subsection{BIOCERAMICS APPLICATIONS IN TISSUE ENGINEERING}

A diversity of clinical procedures using bioceramics include bone grafting, drug delivery, gene transfection, and for bone cancer treatment (84-86). Alongside is the possibility to combine them with bioactive signaling molecules and/or stem cells that provide important cues and signals promoting cells adhesion, proliferation, differentiation, and metabolic activity for the in vivo regeneration process. These bioactive molecules encompass growth factors (with proliferationinducing effects), mitogens (that stimulate cell division), and morphogens (that control generation of tissue form). Bone morphogenetic proteins (BMPs) growth factors are the most significantly used for bone growth and healing, namely in spinal fusion, long bone defects, and oral and maxillofacial surgery, due to their osteoinduction ability (87, 88). Stem cells (human MSCs, human bone marrow stromal cells (hBMSCs), human endometrial stem cells, adipose-derived stem cells) have promising outcome of functional bone recovery, with good implant integration and host bone formation post-surgery (89). For instance, an interesting recent study reported that CPCbased scaffold combining mesoporous silica with recombinant human BMP-2 (rhBMP-2) might provide a solution to issues of tissue necrosis during the regeneration process by facilitating vascularization and osteogenesis (90). The scaffolds induced the osteogenic differentiation of hBMSCs and demonstrated abundant new vessel formation, as well as rapid rates of osteogenesis in vivo owing to the collaborative effects of the biomaterials and growth factor.

Currently there is a range of ceramic products made of alumina/zirconia, bioactive glass and glassceramics, and CaPs-based implants as porous and fibrous scaffolds, and hydrogels $(60,91,92)$. For instance, Oliveira et al. (93) prepared porous HA scaffolds with highly interconnectivity, using an organic sacrifice template, for bone TE (Figure 5). In vitro cell/material interaction tests using rat bone marrow stromal cells (RBMSCs) demonstrated that the cells adhered, proliferated well and remained viable on the scaffolds.
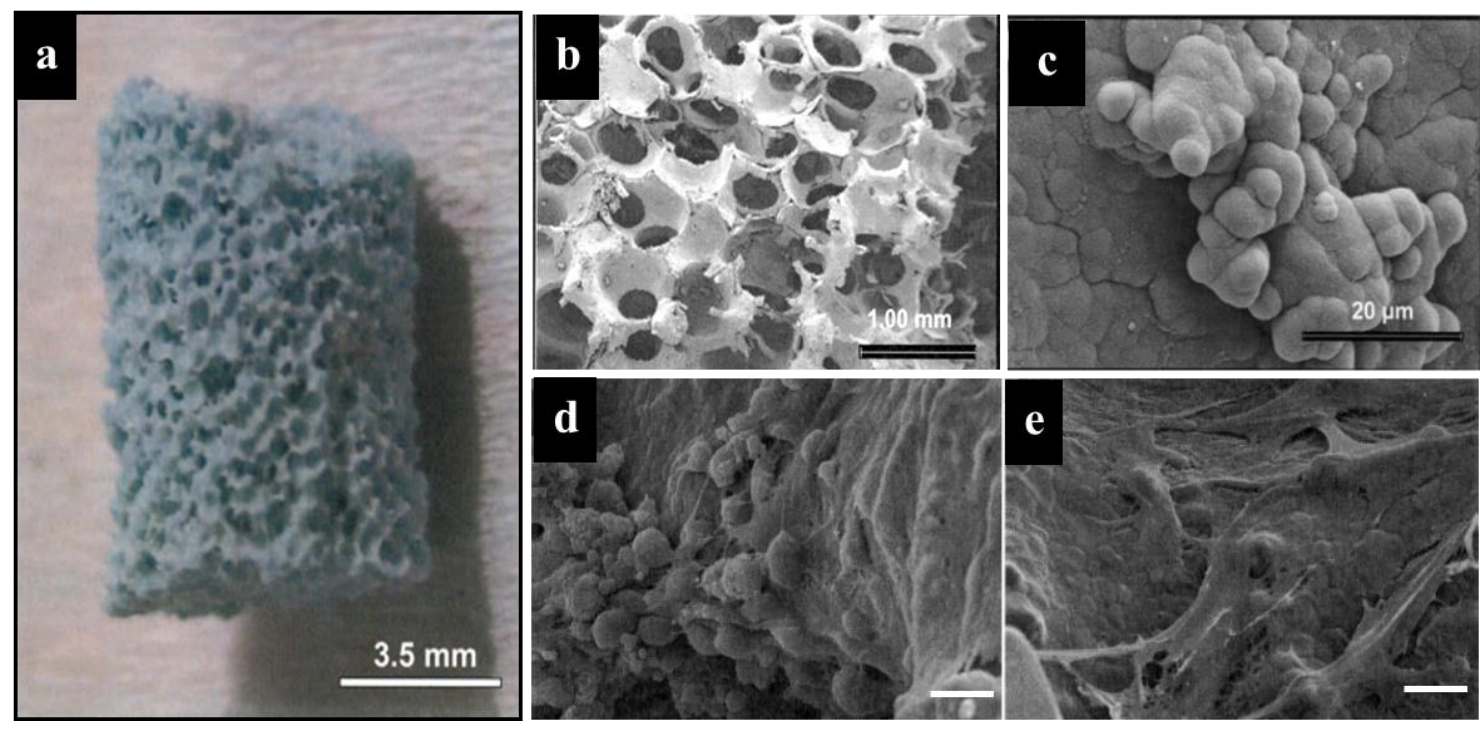
FIGURE 5. HA porous scaffold: (a) macroscopic image, (b) microstructure, (c) microstructure after immersion in SBF for 7 days showing the "cauliflower like" morphology of apatite formed on the scaffold surface, and microstructure showing RBMSCs seeded after culturing for (d) $24 \mathrm{~h}$ and (e) 7 days (scale bar: $10 \mu \mathrm{m}$ ). Reprinted from Ref. (93), with permission.

Mainly of these bioceramic implants are used in non-load-bearing applications, or compressive load situations, owing to their biomechanical limitations, namely as bone fillers of defects in reconstruction surgery, middle ear repair, vertebral, and iliac crest replacements $(57,58,94)$. However, bioceramics-based composite scaffolds have appear as an alternative to circumvent this drawback and to be used to engineer hard tissues. An example is the production of CaPs-based composite scaffolds showing worthy mechanical properties and stability, and self-mineralization capability without cytotoxicity for bone TE $(4,93)$. Our group has been proposed composite porous scaffolds using $\mathrm{CaPs}$ and biodegradable and biopolymeric matrices (i.e., proteins, polysaccharides, and glycosaminoglycans) as a strategy for TE and regeneration $(4,6,7,95)$. For example, silk fibroin/nanosized CaPs composite scaffold provided an optimal microenvironment in terms of porosity and pore interconnectivity, and physicochemical structure, with selfmineralization capability and no cytotoxicity (Figure 6$)(4,96)$. Further, the incorporation of $\mathrm{CaP}$ in the silk fibroin matrix promoted the attachment, viability, and proliferation of the hASCs (96).
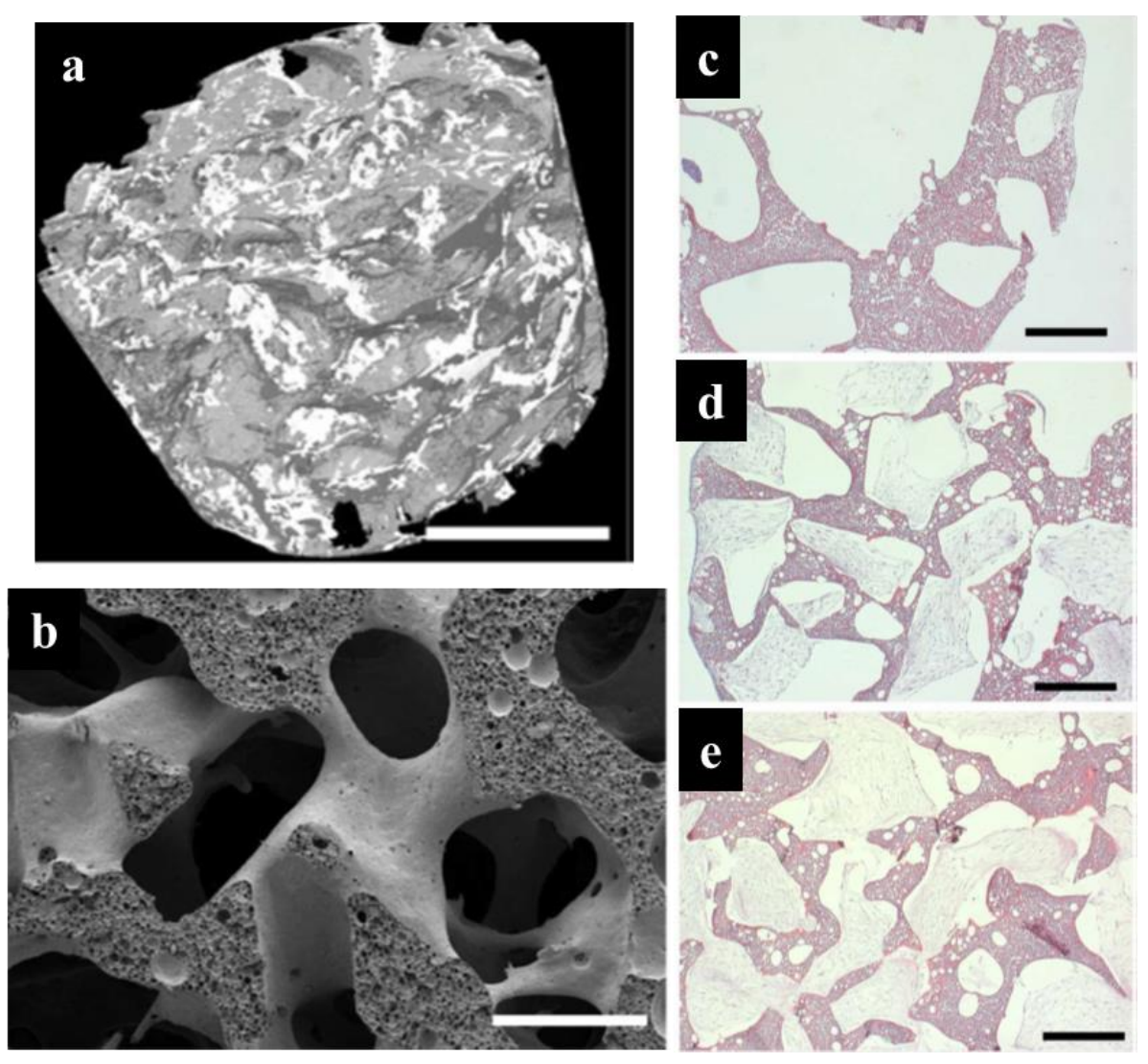
FIGURE 6. Silk fibroin/CaPs composite scaffolds: (a) 3D Micro-CT image showing CaP (white region) and silk fibroin matrix (gray region), (b) microstructure, and (c)-(e) H\&E staining of hASCs cultured on the scaffolds for 3, 7, and 14 days, respectively. Scale bar: $500 \mathrm{~mm}$. Reprinted from Ref.(96), with permission.

Extensive studies have also reported bioactive glass ceramic-based composites for the regeneration of hard and soft tissues. For instance, it was shown that a porous tri-layered nanocomposite scaffold composed of chitin poly (lactic-co-glycolic acid)/nano bioactive glass ceramic/cementum protein 1 as the cementum layer, chitin- poly (lactic-co-glycolic acid)/fibroblast growth factor 2 as the periodontal layer, and chitin- poly (lactic-co-glycolic acid)/nano bioactive glass ceramic/platelet-rich plasma derived growth factors as the alveolar bone layer, is cytocompatible and favored cementogenic, fibrogenic, and osteogenic differentiation of human dental follicle stem cells (97). The scaffold with growth factors demonstrates complete defect closure and healing with new cancellous-like tissue formation and formation of new cementum, fibrous periodontal tissue, and alveolar bone with well-defined bony trabeculae in comparison to the other three groups, upon implantation into rabbit maxillary periodontal defects. Gantar et al. (98) prepared gellan-gum hydrogels reinforced with bioglass to improve the microstructure and the mechanical properties of the biomaterial for bone TE. The hydrogels exhibited an open and well-interconnected porosity of $\sim 80 \%$ and a pore size of $\sim 100-200 \mu \mathrm{m}$, recommended for bone TE scaffolding. Moreover, the ions released from the bioglass conferred the possibility to mineralize in vitro when combined with adipose stem cells.

An overview of bioceramics for varied TE purposes are summarized in Table 1.2.

TABLE 1.2 Summary of bioceramics in different TE applications.

\begin{tabular}{|c|c|c|c|}
\hline Application & Bioceramic materials & Function & References \\
\hline Maxillofacial surgery & $\begin{array}{l}\text { Bioglass } ®, \mathrm{HA} \text { and } \beta- \\
\text { TCP scaffolds, biphasic } \\
\text { CaPs; self-setting CPCs }\end{array}$ & $\begin{array}{l}\text { Repair/replacement of lost teeth; } \\
\text { filling of jaws defects; } \\
\text { reconstruction of mandible and } \\
\text { temporomandibular joint }\end{array}$ & $(94,99)$ \\
\hline Orbital surgery & $\begin{array}{c}\text { Alumina, HA, } \\
\text { Bioglass }{ }^{\circledR}\end{array}$ & $\begin{array}{l}\text { Improving prosthesis motility } \\
\text { resulting in a very natural- } \\
\text { appearing eye; orbital floor } \\
\text { fractures repair }\end{array}$ & $(100,101)$ \\
\hline
\end{tabular}




\begin{tabular}{|c|c|c|c|}
\hline Dental surgery & $\begin{array}{l}\text { Alumina, zirconia, } \\
\text { bioglass, HA }\end{array}$ & $\begin{array}{c}\text { Replace diseased, damaged or } \\
\text { loosened teeth }\end{array}$ & (102) \\
\hline $\begin{array}{l}\text { Periodontal } \\
\text { regeneration }\end{array}$ & $\begin{array}{c}\text { Alumina, zirconia, HA } \\
\text { and } \beta \text {-TCP } \\
\text { nanoparticles, and } \\
\text { bioactive glasses }\end{array}$ & $\begin{array}{l}\text { Promote enamel, dentin and } \\
\text { periodontium healing; } \\
\text { differentiation and proliferation } \\
\text { of ameloblasts, odontoblasts, } \\
\text { cementoblasts, osteoblasts and } \\
\text { fibroblasts }\end{array}$ & $(88,103)$ \\
\hline Lung tissue engineering & Bioglass ${ }^{\circledR}$ composite & $\begin{array}{l}\text { Adhesion and proliferation of } \\
\text { human lung epithelial type II } \\
\text { cells }\end{array}$ & (104) \\
\hline Joint arthroplasty & $\begin{array}{c}\text { Alumina, zirconia, } \\
\text { bioglasses and HA } \\
\text { coatings of acetabular } \\
\text { cup }\end{array}$ & $\begin{array}{c}\text { Osteoconduction and } \\
\text { osteointegration of prosthetic } \\
\text { devices; To reduce wear and } \\
\text { inflammatory response }\end{array}$ & (105) \\
\hline $\begin{array}{c}\text { Bone defects and } \\
\text { diseases }\end{array}$ & $\begin{array}{c}\text { Bioglass, } \mathrm{CaPs} \text {, and } \\
\text { CPCs }\end{array}$ & $\begin{array}{l}\text { Filling bone defects; Repair and } \\
\text { regeneration of damaged bone }\end{array}$ & $(25,53,106)$ \\
\hline Spinal surgery & $\begin{array}{c}\text { Zirconia, bioglass, and } \\
\text { CPCs }\end{array}$ & $\begin{array}{l}\text { Immobilize vertebrae to protect } \\
\text { spinal cord; high compressive } \\
\text { strength }\end{array}$ & $(107,108)$ \\
\hline Wound healing & $\begin{array}{l}\text { Silver doped bioactive } \\
\text { glass, Bioglass }{ }^{\circledR}\end{array}$ & $\begin{array}{l}\text { Bioactive, antimicrobial and } \\
\text { bactericidal properties to the } \\
\text { sutures }\end{array}$ & (109) \\
\hline Cosmetics & $\begin{array}{l}\text { Bioglass (Vitryxx }{ }^{\circledR}, \\
\text { Schott AG) }\end{array}$ & $\begin{array}{l}\text { Antiaging benefits, such as } \\
\text { reducing redness and wrinkles }\end{array}$ & (110) \\
\hline
\end{tabular}

\subsection{CLINICAL TRIALS}

Human clinical research studies conducted around the world are designed to answer specific questions about biomedical or behavioral interventions, including new treatments and known interventions that warrant further study and comparison. Clinical trials give data on products safety and efficacy and are only conducted after approval of the health ethics committee. Table 1.3 provides the completed and ongoing (with no reported results so far) clinical research trials for TE applications using different types of bioceramics.

The process of the products commercialization for implantation involves multiple stages of R\&D replications before reaching the final stages of approval from the governing bodies. R\&D stages ensure efficacy and safety of the devices, involving the fabrication of medical grade scaffolds followed by animal testing under regulatory approved conditions. The FDA provides regulatory 
guidance and approval for biomaterials and devices and classified them according the associated risk. Fracture fixation devices are classified as Class 2 - medium risk, while devices for organs replacement, such as heart valves, are Class 3 (111).

Up to now, for bone regeneration there are no tissue engineered approaches fully approved for clinical application. Instead, just engineered materials/scaffolds already regulatory approved are arriving in the clinic as bone grafts (without the combination of cells), such as Infuse ${ }^{\circledR}$ Bone Graft (Medtronic Sofamor Danek) used for fusion of spinal cage, Osigraft (Stryker Biotech) for long bone non-unions applications, and Grafton ${ }^{\circledR}$ Orthoblend (OsteoTech) as a bone void filler for small and large defects, have been successfully reported. Despite their efficacy in bone regeneration, clinical translation of scaffold-based bone therapies is limited to small defects due to insufficient mechanical integrity.

A remarkable and largest commercial is the use of bioactive glass in toothpastes. A bioglass 45S5 particulate, named NovaMin ${ }^{\circledR}$ (NovaMin Technology, FL, owned by GlaxoSmithKline, UK since 2010) and fluoride-releasing bioactive glass, denominated BioMinF ${ }^{\circledR}$ (BioMin Technologies Ltd, London, UK) were designed to promote a partial remineralization of a demineralized enamel, as well as, a whitening effect and reduce tooth sensitivity $(110,112)$.

TABLE 1.3 List of completed and ongoing clinical trials using bioceramics for TE applications. Information obtained from https://clinicaltrials.gov/.

\begin{tabular}{|c|c|c|c|c|c|}
\hline NCT number & $\begin{array}{l}\text { Date and } \\
\text { status }\end{array}$ & Study & $\begin{array}{l}\text { Patients } \\
\text { age }\end{array}$ & Follow-up & Procedure \\
\hline NCT00200603 & 2005 & $\begin{array}{c}\text { Autograft Versus Calcium } \\
\text { Phosphate Macroporous } \\
\text { Bioceramics as Bone } \\
\text { Substitute for Tibial } \\
\text { Valgus Osteotomy }\end{array}$ & $\begin{array}{l}\text { Adult } \\
\text { and } \\
\text { senior }\end{array}$ & n.d. & Tibial valgus osteotomy \\
\hline NCT00900718 & $\begin{array}{l}\text { 2006-2008 } \\
\text { Conpleted }\end{array}$ & $\begin{array}{c}\text { Comparison of Straumann } \\
\text { Bone Ceramic and Bio- } \\
\text { Oss in Combination With } \\
\text { Guided Tissue } \\
\text { Regeneration for Volume } \\
\text { Preservation of Alveolar } \\
\text { Ridge After Tooth } \\
\text { Extraction }\end{array}$ & $18-75$ yrs & n.d. & Bone augmentation \\
\hline NCT01147315 & $\begin{array}{l}\text { 2009-2016 } \\
\text { Completed }\end{array}$ & $\begin{array}{c}\text { Prospective Study of } \\
\text { Hybrid Bone Substitution } \\
\text { With Calcium-phosphate } \\
\text { Ceramic Biomaterial and } \\
\text { Autologous Bone Marrow }\end{array}$ & $18-75$ yrs & n.d. & Hybrid bone substitution \\
\hline
\end{tabular}




\begin{tabular}{|c|c|c|c|c|c|}
\hline & & $\begin{array}{c}\text { for Mandibular } \\
\text { Osteoradionecrosis } \\
\text { Treatment }\end{array}$ & & & \\
\hline NCT01813188 & $\begin{array}{c}\text { 2011-2014 } \\
\text { Completed } \\
\text { (Phase 2) }\end{array}$ & $\begin{array}{l}\text { Non-inferiority and lower } \\
\text { morbidity of the use of } \\
\text { bone marrow } \\
\text { mononuclear cells seeded } \\
\text { onto a porous matrix of } \\
\text { calcium phosphate, for the } \\
\text { consolidation of tibial } \\
\text { bone defects } \\
\text { (pseudoarthrosis), } \\
\text { compared with autologous } \\
\text { bone graft }\end{array}$ & $18-75 \mathrm{yrs}$ & $6 \mathrm{mths}$ & $\begin{array}{l}\text { Autologous bone marrow } \\
\text { cells seeded onto a } \\
\text { porous tricalcium } \\
\text { phosphate ceramic and } \\
\text { demineralized bone } \\
\text { matrix }\end{array}$ \\
\hline NCT01282034 & $\begin{array}{l}\text { 2011-2016 } \\
\text { Completed }\end{array}$ & $\begin{array}{l}\text { Multicenter Randomized } \\
\text { Controlled Trial for the } \\
\text { Treatment of Knee } \\
\text { Chondral and } \\
\text { Osteochondral Lesions: } \\
\text { Marrow Stimulation } \\
\text { Techniques vs MaioRegen }\end{array}$ & $18-60 \mathrm{yrs}$ & $24 \mathrm{mths}$ & $\begin{array}{c}\text { Marrow stimulation - } \\
\text { Drilling or Microfractures }\end{array}$ \\
\hline NCT01824706 & $\begin{array}{l}\text { 2012-2016 } \\
\text { Completed }\end{array}$ & $\begin{array}{c}\text { A Prospective, } \\
\text { Multicenter Observational } \\
\text { Study Evaluating the Long } \\
\text { Term Safety in Terms of } \\
\text { Explantation Rate and } \\
\text { Number of Infections of } \\
\text { the Custom-made } \\
\text { Bioceramic Implant } \\
\text { CustomBone }^{\mathrm{TM}}\end{array}$ & $\begin{array}{l}\text { Child, } \\
\text { adult, } \\
\text { and } \\
\text { senior }\end{array}$ & $2 \mathrm{yrs}$ & Craniectomy \\
\hline NCT02389569 & $\begin{array}{c}2016 \\
\text { Completed }\end{array}$ & $\begin{array}{c}\text { Clinical Study of } \\
\text { Biosilicate Under Resin } \\
\text { Composite Restorations in } \\
\text { Caries Affected Teeth }\end{array}$ & $18-45$ yrs & $18 \mathrm{mths}$ & Dental caries \\
\hline NCT00841152 & 2009-2018 & $\begin{array}{l}\text { Comparison of two } \\
\text { synthetic ceramic bone } \\
\text { graft substitutes, bioactive } \\
\text { glass and beta-tricalcium } \\
\text { phosphate, in filling of } \\
\text { contained bone defects } \\
\text { following surgical } \\
\text { evacuation of benign bone } \\
\text { tumor or tumor-like } \\
\text { conditions. }\end{array}$ & $\begin{array}{l}\text { Adult } \\
\text { and } \\
\text { senior }\end{array}$ & $12 \mathrm{mths}$ & $\begin{array}{l}\text { Hand and long-bone } \\
\text { defects filling }\end{array}$ \\
\hline
\end{tabular}




\begin{tabular}{|c|c|c|c|c|c|}
\hline NCT01742260 & $\begin{array}{c}\text { 2013-2017 } \\
\text { Phase } 1\end{array}$ & $\begin{array}{c}\text { A Pilot Study to } \\
\text { Demonstrate Safety and } \\
\text { Feasibility of Cranial } \\
\text { Reconstruction Using } \\
\text { Mesenchymal Stromal } \\
\text { Cells and Resorbable } \\
\text { Biomaterials }\end{array}$ & $18-80$ yrs & n.d. & $\begin{array}{l}\text { Repair of cranial defects } \\
\text { by tissue engineering }\end{array}$ \\
\hline NCT01771302 & $2013-2015$ & $\begin{array}{l}\text { Efficiency of plasma rich } \\
\text { in growth factors in } \\
\text { combination with bone } \\
\text { grafts in the healing of } \\
\text { bone and soft tissues in } \\
\text { lateral sinus floor } \\
\text { elevation }\end{array}$ & $\begin{array}{l}\text { Adult } \\
\text { and } \\
\text { senior }\end{array}$ & $6 \mathrm{mths}$ & Bone healing \\
\hline NCT02910232 & $\begin{array}{c}\text { 2014-2016 } \\
\text { Phase } 3\end{array}$ & $\begin{array}{l}\text { In Vivo Clinical Trial of } \\
\text { Porous Starch - } \\
\text { Hydroxyapatite } \\
\text { Composite Biomaterials } \\
\text { for Bone Regeneration }\end{array}$ & $20-60$ yrs & $6 \mathrm{mths}$ & $\begin{array}{c}\text { Bone void filler of foot } \\
\text { fracture }\end{array}$ \\
\hline NCT01974362 & 2016-2017 & $\begin{array}{l}\text { Monolithic Zirconia Full- } \\
\text { Mouth Implant Supported } \\
\text { Rehabilitation Behavior }\end{array}$ & $\begin{array}{l}\text { Adult } \\
\text { and } \\
\text { senior }\end{array}$ & $12 \mathrm{mths}$ & $\begin{array}{c}\text { Place dental implants in } \\
\text { both jaws (maxilla and } \\
\text { mandible) according to } \\
\text { manufacturer } \\
\text { specifications }\end{array}$ \\
\hline
\end{tabular}

n.d.: not defined

\subsection{CONCLUDING REMARKS AND FUTURE OUTLOOK}

Bioceramics have been used very successfully within the human body by repairing and regenerating bone faster that would not restore by other means. These biomaterials are commonly used in orthopedic and dental surgery, but they are potentially suitable for a wide range of essential TE applications. TE has much to bring in respect to combining biomaterials, growth factors/bioactive molecules and cells. Innovative strategies present some of the current challenges in the field, and may constitute major breakthroughs in the future. Bioceramics offer desirable characteristics such as biocompatibility, chemical inertness in biological mediums and hardness, but they have low resistance to traction. Ongoing research involves the chemistry, composition, and micro- and nanostructure of the materials to improve the mechanical integrity of the bioceramics upon implantation, and appropriate porosity for the cellular adhesion, proliferation and differentiation. Biomimetic strategies designed for TE scaffolding have been concentrated on 
3D-based porous and dense scaffolds and fibres, and hydrogels. The latter ones are of particular interest due to their high water content, besides biodegradability and biocompatibility. Although there have been significant advances in engineer new tissues, future developments in order to achieve major improvements should be focused and turn them into a clinically viable strategy. Strategies should be devoted on the clear understanding of the bioceramics-tissue interactions, and hierarchical structure for long-term service, and the related mechanical strength, especially the fatigue limit under periodic external stress.

\section{ACKNOWLEDGMENTS}

The authors thank to the project FROnTHERA (NORTE-01-0145-FEDER-000023), supported by Norte Portugal Regional Operational Programme (NORTE 2020), under the PORTUGAL 2020 Partnership Agreement, through the European Regional Development Fund (ERDF). The financial support from the Portuguese Foundation for Science and Technology to M-ERA-NET/0001/2014 project, for the fellowship grant (SFRH/BPD/108763/2015) and for the funds provided under the program Investigador FCT 2012 and 2015 (IF/00423/2012 and IF/01285/2015) are also greatly acknowledge.

\section{REFERENCES}

1. Salinas AJ, Vallet-Regi M. Bioactive ceramics: from bone grafts to tissue engineering. RSC Advances. 2013;3(28):11116-31.

2. Hasan MS, Ahmed I, Parsons AJ, Rudd CD, Walker GS, Scotchford CA. Investigating the use of coupling agents to improve the interfacial properties between a resorbable phosphate glass and polylactic acid matrix. Journal of Biomaterials Applications. 2013;28(3):354-66.

3. Pina S, Oliveira JM, Reis RL. Natural-Based Nanocomposites for Bone Tissue Engineering and Regenerative Medicine: A Review. Advanced Materials. 2015;27(7):1143-69.

4. Yan LP, Silva-Correia J, Correia C, Caridade SG, Fernandes EM, Sousa RA, et al. Bioactive macro/micro porous silk fibroin/nano-sized calcium phosphate scaffolds with potential for bone-tissue-engineering applications. Nanomedicine (Lond). 2013;8(3):359-78.

5. Oliveira MB, Mano JF. Polymer-based microparticles in tissue engineering and regenerative medicine. (1520-6033 (Electronic)).

6. Yan L, Salgado A, Oliveira J, Oliveira A, Reis R. De novo bone formation on macro/microporous silk and silk/nano-sized calcium phosphate scaffolds. J Bioact Comp Pol. 2013;28:439-52.

7. Yan L-P, Silva-Correia J, Oliveira MB, Vilela C, Pereira H, Sousa RA, et al. Bilayered silk/silk-nanoCaP scaffolds for osteochondral tissue engineering: In vitro and in vivo assessment of biological performance. Acta Biomaterialia. 2015;12:227-41.

8. Dehghani F, Annabi N. Engineering porous scaffolds using gas-based techniques. Current Opinion in Biotechnology. 2011;22:661-6. 
9. Hou Q, Grijpma D, Feijen J. Porous polymeric structures for tissue engineering prepared by a coagulation, compression moulding and salt leaching technique. Biomaterials. 2003;24:1937-47.

10. Liapis A, Pikal M, Bruttini R. Research and development needs and opportunities in freeze drying. Dry Technol. 1996;14:1265-300.

11. vandeWitte P, Dijkstra P, vandenBerg J, Feijen J. Phase separation processes in polymer solutions in relation to membrane formation. J Memb Sci. 1996;117:1-31.

12. Gu BK, Choi DJ, Park SJ, Kim MS, Kang CM, Kim C-H. 3-dimensional bioprinting for tissue engineering applications. Biomaterials Research. 2016;20(1):12.

13. Silva TH, Alves A, Ferreira BM, Oliveira JM, Reys LL, Ferreira RJF, et al. Materials of marine origin: a review on polymers and ceramics of biomedical interest. International Materials Reviews. 2012;57(5):276-306.

14. Oliveira JM, Grech JMR, I. B. Leonor, Mano JF, Reis RL. Calcium-phosphate derived from mineralized algae for bone tissue engineering applications. Materials Letters. 2007;61:34959.

15. Correlo VM, Oliveira JM, Mano JF, Neves NM, Reis RL. CHAPTER 32 - Natural Origin Materials for Bone Tissue Engineering - Properties, Processing, and Performance A2 Atala, Anthony. In: Lanza R, Thomson JA, Nerem R, editors. Principles of Regenerative Medicine (Second edition). San Diego: Academic Press; 2011. p. 557-86.

16. Oliveira J, Costa S, Leonor I, Malafaya P, Mano J, Reis R. Novel hydroxyapatite/carboxymethylchitosan composite scaffolds prepared through an innovative "autocatalytic" electroless coprecipitation route. J Biomed Mater Res A. 2009;88:470-80.

17. Oliveira JM, Kotobuki N, Tadokoro M, Hirose M, Mano JF, Reis RL, et al. Ex vivo culturing of stromal cells with dexamethasone-loaded carboxymethylchitosan/poly(amidoamine) dendrimer nanoparticles promotes ectopic bone formation. Bone.46(5):1424-35.

18. Fomin A, Barinov S, Ievlev V, Smirnov V, Mikhailov B, Belonogov E, et al. Nanocrystalline hydroxyapatite ceramics produced by low-temperature sintering after high-pressure treatment. Doklady Chem. 2008;418:22-5.

19. Pina S, Ferreira J. Brushite-Forming Mg-, Zn- and Sr-Substituted Bone Cements for Clinical Applications. Materials. 2010;3:519-35.

20. Tomoaia G, Mocanu A, Vida-Simiti I, Jumate N, Bobos LD, Soritau O, et al. Silicon effect on the composition and structure of nanocalcium phosphates: In vitro biocompatibility to human osteoblasts. Mater Sci Eng C Mater Biol Appl. 2014;37:37-47.

21. Vallet-Regi M, Arcos D. Silicon substituted hydroxyapatites. A method to upgrade calcium phosphate based implants. Journal of Materials Chemistry. 2005;15(15):1509-16.

22. Kose N, Otuzbir A, Peksen C, Kiremitci A, Dogan A. A silver ion-doped calcium phosphatebased ceramic nanopowder-coated prosthesis increased infection resistance. Clin Orthop Relat Res. 2013;471(8):2532-9.

23. LeGeros RZ, Kijkowska R, Bautista C, Retino M, LeGeros JP. Magnesium incorporation in apatites: Effect of CO3 and F. Journal of Dental Research. 1996;75:60-.

24. Mestres G, Le Van C, Ginebra M-P. Silicon-stabilized $\alpha$-tricalcium phosphate and its use in a calcium phosphate cement: Characterization and cell response. Acta Biomaterialia. 2012;8(3):1169-79.

25. Pina S, Vieira SI, Rego P, Torres PMC, Goetz-Neunhoeffer F, Neubauer J, et al. Biological responses of brushite-forming $\mathrm{Zn}$ - and $\mathrm{ZnSr}$-substituted b-TCP bone cements. Eur Cells Mater (in press). 2010;20:162-77 
26. Maccauro G, Iommetti PR, Raffaelli L, Manicone PF. Alumina and zirconia ceramic for orthopaedic and dental devices. Biomaterials applications for nanomedicine: InTech; 2011.

27. Ghaemi MH, Reichert S, Krupa A, Sawczak M, Zykova A, Lobach K, et al. Zirconia ceramics with additions of Alumina for advanced tribological and biomedical applications. Ceramics International. 2017;43(13):9746-52.

28. Kolos E, Ruys A. Biomimetic Coating on Porous Alumina for Tissue Engineering: Characterisation by Cell Culture and Confocal Microscopy. Materials. 2015;8(6):3584.

29. Greenspan DC. Glass and Medicine: The Larry Hench Story. International Journal of Applied Glass Science. 2016;7(2):134-8.

30. Biamino S, Fino P, Pavese M, Badini C. Alumina-zirconia-yttria nanocomposites prepared by solution combustion synthesis. Ceramics International. 2006;32(5):509-13.

31. Kurtz SM, Kocagöz S, Arnholt C, Huet R, Ueno M, Walter WL. Advances in zirconia toughened alumina biomaterials for total joint replacement. Journal of the Mechanical Behavior of Biomedical Materials. 2014;31:107-16.

32. Pieralli S, Kohal RJ, Jung RE, Vach K, Spies BC. Clinical Outcomes of Zirconia Dental Implants: A Systematic Review. Journal of Dental Research. 2016;96(1):38-46.

33. Nakamura K, Adolfsson E, Milleding P, Kanno T, Örtengren U. Influence of grain size and veneer firing process on the flexural strength of zirconia ceramics. European Journal of Oral Sciences. 2012;120(3):249-54.

34. Benzaid R, Chevalier J, Saâdaoui M, Fantozzi G, Nawa M, Diaz LA, et al. Fracture toughness, strength and slow crack growth in a ceria stabilized zirconia-alumina nanocomposite for medical applications. Biomaterials. 2008;29(27):3636-41.

35. Afzal A. Implantable zirconia bioceramics for bone repair and replacement: A chronological review. Materials Express. 2014;4(1):1-12.

36. http://www.cinn.es/mathys-orthopaedics-files-an-opposition-to-ceramtecs-patent-onmedical-use-of-biolox-delta/.

37. http://www.nevz-ceramics.com/en/produktyi-i-materialyi/biokeramika.html.

38. Rawlings RD. Bioactive glasses and glass-ceramics. Clinical Materials. 1993;14(2):155-79.

39. Rahaman MN, Day DE, Sonny Bal B, Fu Q, Jung SB, Bonewald LF, et al. Bioactive glass in tissue engineering. Acta Biomaterialia. 2011;7(6):2355-73.

40. Jones JR. Review of bioactive glass: From Hench to hybrids. Acta Biomaterialia. 2013;9(1):4457-86.

41. Lobel KD, Hench LL. In-vitro protein interactions with a bioactive gel-glass. Journal of SolGel Science and Technology. 1996;7(1-2):69-76.

42. Gorustovich AA, Roether JA, Boccaccini AR. Effect of bioactive glasses on angiogenesis: a review of in vitro and in vivo evidences. Tissue engineering Part B, Reviews. 2010;16(2):199-207.

43. Xynos ID, Edgar AJ, Buttery LDK, Hench LL, Polak JM. Ionic Products of Bioactive Glass Dissolution Increase Proliferation of Human Osteoblasts and Induce Insulin-like Growth Factor II mRNA Expression and Protein Synthesis. Biochemical and Biophysical Research Communications. 2000;276(2):461-5.

44. Hench LL. Bioceramics. J Amer Ceram Soc. 1998;81:1705-28.

45. Huang W, Day D, Kittiratanapiboon K, Rahaman M. Kinetics and mechanisms of the conversion of silicate (45S5), borate, and borosilicate glasses to hydroxyapatite in dilute phosphate solutions. Journal of Materials Science: Materials in Medicine. 2006;17(7):58396. 
46. Marikani A, Maheswaran A, Premanathan M, Amalraj L. Synthesis and characterization of calcium phosphate based bioactive quaternary $\mathrm{P} 2 \mathrm{O} 5-\mathrm{CaO}-\mathrm{Na} 2 \mathrm{O}-\mathrm{K} 2 \mathrm{O}$ glasses. Journal of Non-Crystalline Solids. 2008;354(33):3929-34.

47. Pickup DM, Newport RJ, Knowles JC. Sol-Gel Phosphate-based Glass for Drug Delivery Applications. Journal of Biomaterials Applications. 2010;26(5):613-22.

48. Fu Q, Rahaman MN, Fu H, Liu X. Silicate, borosilicate, and borate bioactive glass scaffolds with controllable degradation rate for bone tissue engineering applications. I. Preparation and in vitro degradation. J Biomed Mater Res A. 2010;95(1):164-71.

49. Knowles JC. Phosphate based glasses for biomedical applications. Journal of Materials Chemistry. 2003;13(10):2395-401.

50. Xie Z, Cui X, Zhao C, Huang W, Wang J, Zhang C. Gentamicin-Loaded Borate Bioactive Glass Eradicates Osteomyelitis Due to Escherichia coli in a Rabbit Model. Antimicrobial Agents and Chemotherapy. 2013;57(7):3293-8.

51. Brown RF, Rahaman MN, Dwilewicz AB, Huang W, Day DE, Li Y, et al. Effect of borate glass composition on its conversion to hydroxyapatite and on the proliferation of MC3T3E1 cells. Journal of Biomedical Materials Research Part A. 2009;88A(2):392-400.

52. Kashif I, Soliman AA, Sakr EM, Ratep A. Effect of different conventional melt quenching technique on purity of lithium niobate ( $\mathrm{LiNbO} 3)$ nano crystal phase formed in lithium borate glass. Results in Physics. 2012;2(0):207-11.

53. Balamurugan A, Rebelo A, Kannan S, Ferreira JMF, Michel J, Balossier G, et al. Characterization and in vivo evaluation of sol-gel derived hydroxyapatite coatings on Ti6Al4V substrates. Journal of Biomedical Materials Research Part B: Applied Biomaterials. 2007;81B(2):441-7.

54. http://nhakhoagiabao.vn/gia-rang-su-loi-titan-125.html.

55. http://ceramics.org/ceramic-tech-today/biomaterials/glass-scaffolds-help-heal-bone.

56. Bohner M. Calcium orthophosphates in medicine: from ceramics to calcium phosphate cements. Injury-International Journal of the Care of the Injured. 2000;31:37-47.

57. Dorozhkin S. Calcium Orthophosphates in Nature, Biology and Medicine Materials. 2009;2:399-498.

58. Dorozhkin SV. Calcium orthophosphates. Journal of Materials Science. 2007;42(4):106195.

59. Bohner M. Physical and chemical aspects of calcium phosphates used in spinal surgery Eur Spine J. 2001;10 114-21.

60. Eliaz N, Metoki N. Calcium Phosphate Bioceramics: A Review of Their History, Structure, Properties, Coating Technologies and Biomedical Applications. Materials. 2017;10(4):104.

61. Le Geros RZ, Le Geros JP. Calcium Phosphate Bioceramics: Past, Present and Future. Key Eng Mater. 2003;3:240-2.

62. Daculsi G, Laboux O, Malard O, Weiss P. Current state of the art of biphasic calcium phosphate bioceramics. Journal of Materials Science-Materials in Medicine. 2003;14(3):195-200.

63. Kannan S, Goetz-Neunhoeffer F, Neubauer J, Ferreira JMF. Ionic substitutions in biphasic hydroxyapatite and beta-tricalcium phosphate mixtures: Structural analysis by rietveld refinement. Journal of the American Ceramic Society. 2008;91(1):1-12.

64. Kannan S, Lemos AF, Ferreira JMF. Synthesis and mechanical performance of biologicallike hydroxyapatites. Chemistry of Materials. 2006;18(8):2181-6. 
65. Elliott JC. Structure and chemistry of the apatites and other calcium orthophosphates. London: Elsevier; 1994.

66. LeGeros RZ, LeGeros JP, Daculsi G, Kijkowska R. Encyclopedia handbook of biomaterials and bioengineering. Marcel Dekker, New York1995.

67. Ginebra MP, Traykova T, Planell JA. Calcium phosphate cements as bone drug delivery systems: A review. Journal of Controlled Release. 2006;113(2):102-10.

68. Takahashi Y, Yamamoto M, Tabata Y. Osteogenic differentiation of mesenchymal stem cells in biodegradable sponges composed of gelatin and beta-tricalcium phosphate. Biomater. 2005;26:35-87-3596.

69. Metzger DS, Driskell TD, Paulsrud JR. Tricalcium phosphate ceramic: a resorbable bone implant: review and current status. J Amer Dent Assoc. 1982;105:1035-48.

70. Monma H, Goto M. Behavior of the a-b phase transformation in tricalcium phosphate. Yohyo-Kyokai-Shi. 1983;91:473-5.

71. Yin X, Stott MJ, Rubio A. Phys Rev B - Condens Matter Mater Phys. 2003;68:205.

72. Kanazawa Te. Inorganic phosphate materials. Materials Science Monographs. Tokyo1989.

73. Brown PW, Martin R. An analysis of hydroxyapatite surface layer formation. J Phys Chem B. 1999;103:1671-5.

74. Brown WE, Chow LC. A New Calcium-Phosphate Setting Cement. J Dent Res. 1983;62:672-.

75. Ginebra MP, Traykova T, Planell JA. Calcium phosphate cements: Competitive drug carriers for the musculoskeletal system? Biomaterials. 2006;27(10):2171-7.

76. Dorozhkin SV. Calcium orthophosphates cements for biomedical application. J Mater Sci: Mater in Med. 2008;43:3028-57.

77. Bohner M. Reactivity of calcium phosphate cements. Journal of Materials Chemistry. 2007;17(38):3980-6.

78. Bohner M, Gbureck U. Thermal reactions of brushite cements. Journal of Biomedical Materials Research Part B-Applied Biomaterials. 2008;84B(2):375-85.

79. Barralet JE, Lilley KJ, Grover LM, Farrar DF, Ansell C, Gbureck U. Cements from nanocrystalline hydroxyapatite. Journal of Materials Science-Materials in Medicine. 2004;15(4):407-11.

80. Bauer TW, Muschler GF. Bone graft materials. An overview of the basic science. Clin Orthop Relat Res. 2000(371):10-27.

81. Pina S, Vieira SI, Torres PMC, Goetz-Neunhoeffer F, Neubauer J, Silva OABdCe, et al. In vitro performance assessment of new brushite-forming Zn- and ZnSr-substituted b-TCP bone cements. J Biomed Mater Res B. 2010;94B:414-20.

82. http://biomaterials-org.securec7.ezhostingserver.com/week/bio20.cfm.

83. Dorozhkin SV. Self-Setting Calcium Orthophosphate Formulations. Journal of Functional Biomaterials. 2013;4(4):209-311.

84. Arcos D, Vallet-Regí M. Bioceramics for drug delivery. Acta Materialia. 2013;61(3):890911.

85. Mostaghaci B, Loretz B, Lehr CM. Calcium Phosphate System for Gene Delivery: Historical Background and Emerging Opportunities. Curr Pharm Design. 2016;22(11):1529-33.

86. Shekhar S, Roy A, Hong D, Kumta PN. Nanostructured silicate substituted calcium phosphate (NanoSiCaPs) nanoparticles - Efficient calcium phosphate based non-viral gene delivery systems. Mater Sci Eng C-Mater Biol Appl. 2016;69:486-95. 
87. Begam H, Nandi SK, Kundu B, Chanda A. Strategies for delivering bone morphogenetic protein for bone healing. Mater Sci Eng C-Mater Biol Appl. 2017;70:856-69.

88. Ogawa K, Miyaji H, Kato A, Kosen Y, Momose T, Yoshida T, et al. Periodontal tissue engineering by nano beta-tricalcium phosphate scaffold and fibroblast growth factor-2 in one-wall infrabony defects of dogs. J Periodont Res. 2016;51(6):758-67.

89. Marcacci M, Kon E, Moukhachev V, Lavroukov A, Kutepov S, Quarto R, et al. Stem cells associated with macroporous bioceramics for long bone repair: 6- to 7-year outcome of a pilot clinical study. Tissue Eng. 2007;13(5):947-55.

90. Li CD, Jiang C, Deng Y, Li T, Li N, Peng MZ, et al. RhBMP-2 loaded 3D-printed mesoporous silica/calcium phosphate cement porous scaffolds with enhanced vascularization and osteogenesis properties. Scientific Reports. 2017;7:12.

91. Baino F, Novajra G, Vitale-Brovarone C. Bioceramics and Scaffolds: A Winning Combination for Tissue Engineering. Frontiers in Bioengineering and Biotechnology. 2015;3:202.

92. Dorozhkin SV. Multiphasic calcium orthophosphate (CaPO4) bioceramics and their biomedical applications. Ceramics International. 2016;42(6):6529-54.

93. Oliveira J, Silva S, Malafaya P, Rodrigues M, Kotobuki N, Hirose M, et al. Macroporous hydroxyapatite scaffolds for bone tissue engineering applications: Physicochemical characterization and assessment of rat bone marrow stromal cell viability. Inc $\mathrm{J}$ Biomed Mater Res A. 2009;91:175-86.

94. Baino F, Perero S, Ferraris S, Miola M, Balagna C, Verné E, et al. Biomaterials for orbital implants and ocular prostheses: Overview and future prospects. Acta Biomaterialia. 2014;10(3):1064-87.

95. Yan L, Oliveira J, Oliveira A, Reis R. Silk Fibroin/Nano-CaP Bilayered scaffolds for Osteochondral Tissue Engineering. Key Eng Mater. 2014;587:245.

96. Yan LP, Oliveira JM, Oliveira AL, Reis RL. In vitro evaluation of the biological performance of macro/micro-porous silk fibroin and silk-nano calcium phosphate scaffolds. Journal of Biomedical Materials Research Part B: Applied Biomaterials. 2015;103(4):88898.

97. Sowmya S, Mony U, Jayachandran P, Reshma S, Kumar RA, Arzate H, et al. Tri-Layered Nanocomposite Hydrogel Scaffold for the Concurrent Regeneration of Cementum, Periodontal Ligament, and Alveolar Bone. Advanced Healthcare Materials. 2017;6(7):13.

98. Gantar A, da Silva LP, Oliveira JM, Marques AP, Correlo VM, Novak S, et al. Nanoparticulate bioactive-glass-reinforced gellan-gum hydrogels for bone-tissue engineering. Materials Science and Engineering: C. 2014;43:27-36.

99. Adamopoulos O, Papadopoulos T. Nanostructured bioceramics for maxillofacial applications. Journal of Materials Science: Materials in Medicine. 2007;18(8):1587-97.

100. Baino F, Vitale-Brovarone C. Bioceramics in ophthalmology. Acta Biomaterialia. 2014;10(8):3372-97.

101. He DS, Zhuang C, Chen C, Xu SZ, Yang XY, Yao CL, et al. Rational Design and Fabrication of Porous Calcium-Magnesium Silicate Constructs That Enhance Angiogenesis and Improve Orbital Implantation. ACS Biomater Sci Eng. 2016;2(9):1519-27.

102. Pieralli S, Kohal RJ, Jung RE, Vach K, Spies BC. Clinical Outcomes of Zirconia Dental Implants: A Systematic Review. Journal of Dental Research. 2017;96(1):38-46. 
103. Sowmya S, Bumgardener JD, Chennazhi KP, Nair SV, Jayakumar R. Role of nanostructured biopolymers and bioceramics in enamel, dentin and periodontal tissue regeneration. Progress in Polymer Science. 2013;38(10):1748-72.

104. Verrier S, Blaker JJ, Maquet V, Hench LL, Boccaccini AR. PDLLA/Bioglass ${ }^{\circledR}$ composites for soft-tissue and hard-tissue engineering: an in vitro cell biology assessment. Biomaterials. 2004;25(15):3013-21.

105. Heimke G, Leyen S, Willmann G. Knee arthoplasty: recently developed ceramics offer new solutions. Biomaterials. 2002;23(7):1539-51.

106. Flautre B, Maynou C, Lemaitre J, Van Landuyt P, Hardouin P. Bone colonization of $\beta$-TCP granules incorporated in brushite cements. J Biomed Mater Res - Appl Biomater. 2002;63:413-7.

107. Sablina T, Savchenko N, Pshenichnyy A, Grigoriev M, Buyakova S, Kulkov S. Development of bioceramic material for spinal surgery implants. IOP Conference Series: Materials Science and Engineering. 2016;140(1):012004.

108. Li H, Zou X, Xue Q, Egund N, Lind M, Bunger C. Anterior lumbar interbody fusion with brantigan cages loaded with bioceramics and platelet rich plasma. Orthop Res Trans. 2003;28:265.

109. Blaker JJ, Nazhat SN, Boccaccini AR. Development and characterisation of silver-doped bioactive glass-coated sutures for tissue engineering and wound healing applications. Biomaterials. 2004;25(7):1319-29.

110. Jones JR, Brauer DS, Hupa L, Greenspan DC. Bioglass and Bioactive Glasses and Their Impact on Healthcare. International Journal of Applied Glass Science. 2016;7(4):423-34.

111. Sullivan F. Advances in tissue engineering. 2011.

112. Dorozhkin SV. Calcium orthophosphates in dentistry. Journal of Materials Science: Materials in Medicine. 2013;24(6):1335-63. 